\title{
Effects of Local Guidelines on Prescribing Practice and Treatment Outcomes in a Long-Stay Psychiatric Facility
}

\author{
Ivana M. Iličković ${ }^{1}$, Aleksandar B. Tomčuk ${ }^{2}$, Jovo M. Djedović \\ Kristina B. Bećir ${ }^{2}$, Slobodan M. Janković ${ }^{3}$ \\ ${ }^{1}$ Farmegra Ltd., Podgorica, Montenegro \\ ${ }^{2}$ Specialized Hospital for Psychiatric Diseases, Dobrota, Kotor, Montenegro \\ ${ }^{3}$ Faculty of Medical Sciences, University of Kragujevac, Kragujevac, Serbia
}

\section{SUMMARY}

Introduction: A gap between evidence-based recommendations for prescribing antipsychotics and its implementation in practice could be overcome by local guidelines.

Aim: The aim of our study was to locally adapt the national guideline for schizophrenia and evaluate its impact on prescribing practice as well as on clinical and humanistic outcomes in a long-stay psychiatric hospital Dobrota in Kotor, Montenegro.

Subjects and Methods: This was academic, prospective, IV phase interventional study, which measured outcome before and after investigators intervention within healthcare system. The study was conducted in two six-months phases separated by implementation of the local guidelines. Prescribing practices and treatment outcomes were monitored in both phases of the study.

Results: Study included 111 patients. Although the guidelines did not influence total volume of prescribed antipsychotics, social functioning and environmental aspects of quality of life were improved.

Conclusions: Writing and adopting the guidelines for local use might be associated with some benefit in humanistic outcomes, but multi-faceted intervention should be considered in order to achieve more substantial impact on prescribing practices and clinical outcomes.

Keywords: guidelines, schizophrenia, antipsychotic polypharmacy, inpatients, outcomes

\section{INTRODUCTION}

Main focus of the multidisciplinary treatment of mental illnesses, especially schizophrenia, is still on the pharmacological therapy in majority of settings [1]. It might be, partly, justified, by the increasing availability of newly identified drugs with improved efficacy, safety, and tolerability profiles (e.g., atypical antipsychotics, selective serotonin reuptake inhibitors, al- ternative mood-stabilizing agents).

Nevertheless, relative cost and complexity of the neuropsychopharmacology advancements have also been emphasised [1,2]. This rendered publication of numerous treatment guidelines and practice recommendation, aiming at best scientific evidence being translated into practice, for improving clini- 
cal, humanistic and economic outcomes of treatment for patients with mental disorders. [1,3-10]. Although it is recognized that appropriate prescribing could improve patient outcomes and cut the expenses [1,11], there is a gap between evidence based recommendations and their implementation in local practices, especially in developing countries [1,12-15]. Several barriers were identified in developing countries that adversely affect implementation of evidence-based guidelines in clinical practice (lack of evidence-based healthcare system [16], lack of political support [16], lack of knowledge and appropriate training of physicians [17], etc.), but still we are far from complete insight into the problem, partially due to social and cultural differences across the countries.

In 2012, the Ministry of Health of Montenegro issued the first National guideline for the treatment of Schizophrenia [7]. Consistent with other guidelines and research findings $[2,13,18]$ antipsychotic polypharmacy (APP) was not supported; advantages of efficacy/tolerability profiles of second-generation antipsychotics (SGA) and effectiveness of clozapine augmentation for treatment resistant patients were elaborated. However, national guidelines did not cover issues such as treatment of chronic schizophrenia patients resistant even to clozapine, treatment of adverse effects of antipsychotics, or optimal dosing regimens.

\section{AIM}

The aim of our study was to locally adapt the national guideline for schizophrenia and evaluate its impact on prescribing practice as well as on clinical and humanistic outcomes in hospital patients with severe mental illnesses in Montenegro.

\section{SUBJECTS AND METHODS}

\section{Subjects with ethical considerations and in- formed consent}

This academic, prospective, IV phase, interventional study, which measured outcome before and after intervention - adaptation and application the national guideline for schizophrenia, was conducted at specialized psychiatric hospital Dobrota in Kotor, Montenegro. The Ethics approval for the study was ob- tained from the Ethics Committee of Clinical Center of Montenegro, Podgorica (No 03/0111941/1), and from the Ethics Committee of Dobrota hospital (No 24-12-09).

This is a 241-bed, non-research facility for patients with severe mental illnesses, with 141 beds for long term patients. The study was conducted during the period from June the $15^{\text {th }}, 2012$, to June the $15^{\text {th }}, 2013$. All chronic patients of this facility (hospitalized for more than 6 months) with the diagnosis of schizophrenia (F20.0-F20.9) were included in the study, except for the patients with concomitant mental retardation or impairment of consciousness.

\section{Methods}

The intervention consisted of development, adoption and implementation of local guideline for pharmacological treatment of schizophrenia in Dobrota hospital. The study had two phases separated by adoption and implementation of the local guideline: the first, sixmonth phase, when baseline prescribing practice in the hospital was monitored, and the second six-months phase, after the guideline were adopted and implemented, when effects of the guidelines to prescribing practice were observed. The guideline was developed initially by an independent expert, and then further refined and adopted by the Expert Board of the Dobrota hospital (composed of psychiatrists), after discussion with all other employed psychiatrists and taking into account their feedback.

All study variables were measured at the end of the respective study phase. The demographic data collected included: age, sex, duration of illness, duration of current hospitalization, type of hospitalization (continuous or interrupted during weekends), psychiatric and other diagnosis. Data about medications, laboratory monitoring and adverse reactions were also collected.

Clinical and humanistic outcomes of the intervention (implementation of local treatment guidelines) - were assessed using standardized rating scales: (1)18-item Brief Psychiatric Rating Scale-BPRS to evaluate clinical status [19]; (2)The Abnormal Involuntary Movement Scale-AIMS was used for assessing occurrence and severity of dyskinesias [20]; (3)Humanistic outcomes were assessed using Euroqol (Serbia (Serbian) EQ-5D-5L) 
Table 1. Demographic characteristics of the study patients
Gender

Age/ years \pm SD (range)

Hospitalization

Mean duration/years \pm SD (range)

Main diagnosis

and WHOQOL (WHOQOL BREF_Serb_Croat_Bosnian). The BPRS and AIMS are scales in the public domain, while permissions for use of EQ-5D-5L and WHOQOL BREF were obtained from copyright holders.

\section{Statistical analysis}

The study data were statistically described by means and standard deviations (for continuous variables) or percentages (for categorical variables). The differences between values of continuous study variables before and after the intervention were tested by Student's Ttest for large, dependent groups, when the values were normally distributed (as tested by Kolmogorov-Smirnov test), and by Wilcoxon's test, when the values were not normally distributed. The differences between values of categorical variables before and after the intervention were tested by Chi-square test. The differences were considered significant if probability of null hypothesis was less than 0.05 .

\section{RESULTS}

Study included 111 subjects. Demographic characteristics and diagnosis are presented in the Table 1. Mean BPRS score of 25.7 ( \pm 12.13 ) demonstrated clinical status of moderately severe illness.

\section{Phase 1}

No adverse event was noted in the first phase of the study. Presence of dyskinesia, as rated by the Assessing involuntary movements (AIMS) scale, was $13.34 \pm 4.89$.

Patient-perceived quality of life on EUROQOL 5D 5L visual analogue scale was $53.6 \%$ ( \pm 26.2 ), and WHOQOL BREF scores in the first phase of the study for the four domains: physical health, psychological, social relationships and environment are presented in the Table 2.

Antipsychotics were prescribed to 108 of 111 patients, at the median daily dose expressed as chlorpromazine equivalent of 546 $\mathrm{mg}$, ranging from 50 to $2600 \mathrm{mg}$. The first generation antipsychotics (FGA) were prescribed to 85 and the second generation to 74 patients. Most of the patients (69.4\%) received combinations of antipsychotics. Antidepressants were co-prescribed to 6 and lithium to 9 patients. Percentages of patients taking anticonvulsants, antiparkinsonian medications and benzodiazepines were: $38.7 \%$, $45 \%$ and $58.6 \%$, respectively.

\section{The intervention}

The local guidelines for pharmacological treatment of schizophrenia were developed by an independent expert in clinical pharmacology (from Faculty of Medical Sciences, University of Kragujevac, Serbia), and then discussed and finally adopted by the Professional Board of Dobrota hospital at the session held on December $21^{\text {st }}, 2012$. The local guidelines for treatment of schizophrenia were based on the National guidelines of Montenegro, and then developed further in following areas: treat-
Table 2. WHOQOL BREF scores in the first phase of the study

\begin{tabular}{|l|c|c|c|c|}
\hline \multicolumn{5}{|c|}{ WHOQOL-BREF } \\
\hline \multicolumn{1}{|c|}{ Domains } & Physical health & Psychological & Social relationships & Environment \\
\hline Mean scores \% & 61.26 & 50.89 & 39.99 & 53.98 \\
\hline SD & 16.21 & 18.59 & 12.70 & 0.79 \\
\hline
\end{tabular}




\begin{tabular}{|l|c|c|c|}
\hline & Phase 1 & Phase 2 & p value \\
\hline FIRST GENERATION ANTIPSYCHOTICS & 85 & 88 & 0.837 \\
\hline SECOND GENERATION ANTIPSYCHOTICS & 74 & 75 & 0.986 \\
\hline BENZODIAZEPINES & 65 & 68 & 0.916 \\
\hline ANTIEPILEPTICS & 43 & 44 & 0.986 \\
\hline ANTIDEPRESSANTS & 6 & 8 & 0.859 \\
\hline ANTIPARKINSONIAN DRUGS & 50 & 50 & 0.988 \\
\hline LITHIUM & 9 & 9 & 1.000 \\
\hline COMBINATION OF ANTPSYCHOTICS & 75 & 79 & 0.783 \\
\hline
\end{tabular}

Table 3. Therapeutic choices before and after the implementation of local guidelines ment of chronic schizophrenia patients resistant to clozapine, treatment of adverse effects of antipsychotics, and optimal dosing regimens of antipsychotics.

\section{Phase 2}

The post hoc therapeutic choices did not demonstrate guideline adherence (Table 3). Treatment with combinations of antipsychotics increased (75 to 79), but not significantly. However, the median daily dose of antipsychotics expressed as chlorpromazine equivalent increased from $546 \mathrm{mg}$ in the first phase to $572 \mathrm{mg}$ (range from 50 to $2600 \mathrm{mg}$ ) in the second study phase $(\mathrm{p}=0.016, \mathrm{Z}=-2.398)$.

Mean scores on the rating scales, before and after the implementation of guidelines, are presented in the Table 4 . Involuntary movements worsened in the second phase of the study, with higher AIMS scores recorded for 63 of 107 patients assessed (Table 4).

Laboratory analyses revealed increase of the blood glucose level (4.94 \pm 0.93 (2.71-8.52) in the phase 1 , and $5.86 \pm 2.25$ (4.04-16.71) in the phase $2, \mathrm{p}=0.005)$ and cholesterol regulation $(5.046 \pm 1.06(1.99-7.7)$ in the phase 1 , and $5.59 \pm 1.31(3.15-8.61)$ in the phase $2, \mathrm{p}=0.023)$ after the adoption of local guidelines, but not that of triglycerides $(2.01 \pm 1.28(0.54-7.7)$ in the phase 1 , and 2.41 $\pm 1.31(3.15-8.61)$ in the phase $2, \mathrm{p}=0.805)$.

There were no significant differences in mean BPRS scores, as well as estimated severity of illness (Table 4 ).

Patient-perception of quality of life assessed by EUROQOL 5D 5L visual analog scale, as well as physical health or psychical

\begin{tabular}{|c|c|c|c|c|c|c|c|c|}
\hline Scale & \multicolumn{4}{|c|}{ AIMS } & \multicolumn{4}{|c|}{ BPRS } \\
\hline $\begin{array}{l}\text { Phase } \\
\text { Domain }\end{array}$ & \multicolumn{2}{|c|}{ phase 1} & \multicolumn{2}{|c|}{ phase 2} & \multicolumn{2}{|c|}{ phase 1} & \multicolumn{2}{|c|}{ phase 2} \\
\hline Mean & \multicolumn{2}{|c|}{13.34} & \multicolumn{2}{|c|}{16.14} & \multicolumn{2}{|c|}{25.70} & \multicolumn{2}{|c|}{27.56} \\
\hline SD & \multicolumn{2}{|c|}{4.89} & \multicolumn{2}{|c|}{7.83} & \multicolumn{2}{|c|}{12.13} & \multicolumn{2}{|c|}{13.13} \\
\hline $\mathrm{p}$ value* & \multicolumn{4}{|c|}{0.000} & \multicolumn{4}{|c|}{0.200} \\
\hline Scale & \multicolumn{4}{|c|}{ EURQOL VAS } & & & & \\
\hline $\begin{array}{l}\text { Phase } \\
\text { Domain }\end{array}$ & \multicolumn{2}{|c|}{ phase 1} & \multicolumn{2}{|c|}{ phase 2} & & & & \\
\hline Mean & \multicolumn{2}{|c|}{53.65} & \multicolumn{2}{|c|}{55.95} & & & & \\
\hline SD & \multicolumn{2}{|c|}{26.20} & \multicolumn{2}{|c|}{26.38} & & & & \\
\hline p value* & \multicolumn{2}{|c|}{0.371} & \multicolumn{2}{|c|}{9} & & & & \\
\hline Scale & \multicolumn{8}{|c|}{ WHOQOL BREF DOMAINS } \\
\hline Phase & phase 1 & phase 2 & phase 1 & phase 2 & phase 1 & phase 2 & phase 1 & phase 2 \\
\hline Domain & I & I & II & II & III & III & IV & IV \\
\hline Mean & 61.26 & 59.60 & 50.89 & 48.84 & 39.99 & 48.53 & 53.98 & 58.48 \\
\hline SD & 16.21 & 16.52 & 18.59 & 15.75 & 12.71 & 15.35 & 0.79 & 14.13 \\
\hline p value* & \multicolumn{2}{|c|}{0.375} & \multicolumn{2}{|c|}{0.158} & \multicolumn{2}{|c|}{0.000} & \multicolumn{2}{|c|}{0.000} \\
\hline
\end{tabular}

Table 4. Scores of the psychiatric and quality of life scales

* Wilcoxon signed rank test 
condition assessed by WHOQOL BREF questionnaire did not significantly change from baseline after adoption of the local guideline. However, quality of life of the patients concerning social and environmental domains significantly improved after adoption of the guideline (Table 4).

\section{DISCUSSION}

Overall, the study showed that adoption of local guideline did not significantly alter prescribing patterns. Antipsychotic polypharmacy remained routinely used with FGAs as prevailing treatment choice and the daily dose in CPZ equivalents has significantly increased. Such result is not surprising, since differing adherence to psychiatric guidelines is documented worldwide [13,15]. Broekema [13] in European pharmaco-epidemiological study, carried out at 45 hospitals in six western European countries, implied that "more than half $(52.9 \%)$ of the patients are not being treated according to the psychiatric handbooks and guidelines". In Canadian schizophrenia treatment services [21] conformance with pharmacological guideline recommendations ranged between $58 \%$ and $90 \%$.

This finding of our study could have been anticipated, since it is recognized that well-designed multifaceted interventions are needed for improving adherence to guideline recommendations [12,22,23]. In Montenegro the first National schizophrenia guideline was published shortly before the study onset (in June 2012), with, to our knowledge, no evidence based supporting interventions for augmenting implementation. Observed guideline non-adherence could be further elaborated within the Cabana's [24] conceptual framework, explaining that before external research evidences (i.e. guidelines) can affect patient outcomes, it first affect physician knowledge, then attitudes, and finally behavior.

Antipsychotic polypharmacy did not decrease after the guideline adoption comparing with baseline. Several other studies have shown that patients receiving APP before the intervention were more likely to receive it at the study end point as well [25-27]. This phenomenon is not characteristic only for the developing countries, and the trend of not decreasing APP is commonly observed in long term studies from North America and Europe, both in national and local settings [28]. APP prevalence in North America increased from $12.7 \%$ in the 1980 s to $17.0 \%$ in the 2000 s. In Europe an increase from the 1980s (17.6\%) to the $1990 \mathrm{~s}(26.3 \%)$ was observed, followed by a plateau in the 2000s (25.0\%) [28].

The extent of APP observed in our study (69.4\% to $73.1 \%)$, was not frequent in the recent literature. Although acknowledging geographical variations (Asia: median $=32 \%$, Europe: median $=23 \%$, North America: median $=16 \%$, and Oceania: median $=16.4 \%$.), a systematic review Galllego [26] found global median of $19.5 \%$ of patients receiving APP. It is also reported that combination treatment occurs between $3 \%$ and $71 \%$, with mostly recorded prevalence rates of between $10 \%$ and $30 \%$ [28]. There are some distinctive features of our study settings that have been described in the literature as correlated with the high extent of APP prescribing. Variables such as: non-teaching hospital settings, less research involvement [29], FGA prescribing, duration of the disease, in patient treatment [30-32], longer inpatient stay [25,27], are found to be associated with higher rates of APP prescribing. Although its efficacy/safety profile is not evidence based, APP is often advocated in the literature with greater illness severity, complexity, chronicity, and refractoriness [27], which are all characteristics of patients in our study.

Median daily dose of antipsychotics significantly increased during the study: from 546 to $572 \mathrm{mg}$ of $\mathrm{CPZ}$ equivalent. Although close to the upper limit, the median dose remained within the recommended range (300$600 \mathrm{mg}$ of CPZ equivalent), but the prescribed daily doses showed considerably large amplitude from 50 to $2600 \mathrm{mg}$ of CPZ equivalent. Previously published studies consistently showed relation between APP and greater total antipsychotic dose $[27,29,34-36]$. In addition, it was recorded that patients treated in the specialized psychiatric facilities were frequently overdosed in comparison with recommendations [37]. Increasing the dose may not necessarily indicate poor quality care, and may be appropriate for non-responders to lower doses. The reasoning is mostly based on the differences between patients who fulfill stringent criteria for inclusion in pivotal randomized controlled trials (RCTs) on which dosing recommendations are usually based, and real life settings $[37,38]$.

There is lack of reported psychopa- 
thology ratings or adverse effects in APP studies, and our study adds value to this, "underresearched area" [28]. The results of BPRS scale consistently revealed no improvement in clinical outcomes. Bearing in mind lack of significant changes in prescribing habits after adoption of the guidelines, these findings were expected. The observed increase in daily dose did not have positive impact on clinical outcomes, and it could be associated with significantly higher score on the AIMS scale. Higher total daily antipsychotic dosing together with extensive FGA prescribing and APP could predispose worsening of involuntary movements. However, there were some positive effects of the intervention on the humanistic outcomes, as shown by WHOQOL scale in social and environmental domains.

The limitation of our study is its single-center character resulting from the fact that Dobrota hospital is the only long-stay psychiatric facility in Montenegro. Besides, the study was conducted shortly after introduction of concept of national evidence-based guidelines in Montenegro, so culture of using guidelines in general was not developed enough among the physicians. The naturalistic setting and sample characteristics obtained using broad inclusion and minimal exclusion criteria, and assessing outcomes using validated scales adds new knowledge about treatment of schizophrenia. Patients with wide age range, extensive period of permanent hospitalization and disease duration, presence of coexisting conditions and co-medications provide context, which is not often presented in the literature due to stringent criteria for sampling in randomized controlled trials.

\section{CONCLUSION}

From the results of our study it could be concluded that mere writing and adopting the guidelines is not sufficient to change established prescribing practice in treatment of schizophrenia, or clinical and humanistic outcomes in developing countries with shortlived culture of evidence-based healthcare; much more has to be done on promotion of the guidelines, including research of effectiveness of various healthcare interventions.

\section{ACKNOWLEDGEMENTS}

This study was financially supported by the
Grant No 404 from Ministry of Science, Montenegro.

\section{CONFLICTS OF INTEREST}

All authors report no conflicts of interest relevant to this article.

\section{REFERENCES}

1. Kreyenbuhl J, Buchanan RW, Dickerson FB, Dixon LB. The schizophrenia patient outcomes research team (PORT): updated treatment recommendations 2009. Schizophrenia bulletin. 2009;36(1):94-103.

2. Lieberman JA, Stroup TS, McEvoy JP, Swartz MS, Rosenheck RA, Perkins DO, Keefe RS, Davis SM, Davis CE, Lebowitz BD, Severe J, Hsiao JK; Clinical Antipsychotic Trials of Intervention effectiveness (CATIE) Investigators. Effectiveness of antipsychotic drugs in patients with chronic schizophrenia. $\mathrm{N}$ Engl J Med. 2005;353(12):1209-23.

3. Kane JM, Agid O, Baldwin ML, Howes O, Lindenmayer JP, Marder S, Olfson M, Potkin SG, Correll CU. Clinical Guidance on the Identification and Management of Treatment - Resistant Schizophrenia. J Clin Psychiatry. 2019 Mar 5;80(2). pii:18com12123.

4. Buchanan RW, Kreyenbuhl J, Kelly DL, Noel JM, Boggs DL, Fischer BA, et al. Schizophrenia $\mathrm{Pa}$ tient Outcomes Research Team (PORT). The 2009 schizophrenia PORT psychopharmacological treatment recommendations and summary statements. Schizophr Bull 2010;36(1):71-93.

5. NICE: National Institute for Health and Care Excellence. CG 82. Schizophrenia: core interventions in the treatment and management of schizophrenia in adults in primary and secondary care (update); 2011. http://www.nice.org.uk/CG82 (accessed 20 March 2013).

6. Scottish Intercollegiate Guidelines Network (SIGN). Management of schizophrenia. Edinburgh: SIGN; 2013. (SIGN publication no. 131). [March 2013]. Available from URL: http://www.sign.ac.uk

7. Stevović-Injac L, Dedović J, Tomčuk A. Radna grupa za izradu i implementaciju kliničkih protokola i smjernica i razvoj Sistema osiguranja kvaliteta. Shizofrenija - Nacionalne smjernice dobre kliničke prakse. Ministry of Health of Montenegro, 2012. http://www.mzdravlja.gov.me/rubrike/nacionaIne-smjernice (accessed 01 July 2013)

8. Management of Bipolar Disorder Working Group. $\mathrm{VA} / \mathrm{DoD}$ clinical practice guideline for management of bipolar disorder in adults. Washington (DC): Department of Veterans Affairs, Department of Defense; 2010 May. 176 p.

9. NICE: National Institute for Clinical Excellence. CG90, CG91. Treatment and management of depression in adults, including adults with a chronic physical health problem; (update) 2009. http:// www.nice.org.uk/CG90 and http:// www.nice.org. 
uk/CG91

10. American Psychiatric Association (APA). Practice guideline for the treatment of patients with major depressive disorder. 3rd ed. Arlington (VA): American Psychiatric Association (APA); 2010 Oct. $152 \mathrm{p}$.

11. Cullen BA, McGinty EE, Zhang $\mathrm{Y}$, Dosreis SC, Steinwachs DM, Guallar E, et al. Guideline-concordant antipsychotic use and mortality in schizophrenia. Schizophr Bull 2013;39(5):1159-68.

12. Institute of Medicine.Improving the Quality of Health Care for Mental and Substance-Use Conditions. Washington, DC: National Academies Press, 2006.

13. BroekemaWJ, de Groot EW, van Harten PN. Simultaneous prescribing of atypical antipsychotics, conventional antipsychotics and anticholinergics-a European study Pharm World Sci 2007; 29:126-130.

14. Killackey E, Jorm A, Alvarez-Jimenez M, McCann TV, Hides L, Couineau AL. Do we do what we know works, and if not why not? Aust $\mathrm{N} Z \mathrm{Z}$ J Psychiatry 2008;42(6):439-44

15. Sweileh WM, Odeh JB, Zyoud SH, Sawalha AF, Ihbeasheh MS. Conformance to schizophrenia treatment guidelines in North West-Bank, Palestine: focus on antipsychotic dosing and polytherapy. BMC Psychiatry 2013;13:179.

16. Baradaran-Seyed Z, Nedjat S, Yazdizadeh B, Nedjat S, Majdzadeh R. Barriers of clinical practice guidelines development and implementation in developing countries: a case study in iran. Int J Prev Med 2013; 4(3): 340-8.

17. Saillour-Glenisson F, Michel P. [Individual and collective facilitators of and barriers to the use of clinical practice guidelines by physicians: a literature review]. Rev Epidemiol SantePublique 2003; 51(1 Pt 1): 65-80.

18. Gaebel W, Weinmann S, Sartorius N, Rutz W, McIntyre JS. Schizophrenia practice guidelines: international survey and comparison. Br J Psychiatry 2005;187:248-55

19. Overall JE, Gorham DR. The Brief Psychiatric Rating Scale. Psychological Reports. 1962;10:799812.

20. Abnormal involuntary movement scale [AIMS] (1976). National Institute of Mental Health Psychopharmacology Research Branch. Guy W. (1976). ECDEU assessment manual for psychopharmacology. Rev. Rockville, MD: U.S. National Institute of Health, Psychopharmacology Research Branch. Pg. 534-537.

21. Addington $D$, McKenzie $E$, Smith $H$, Chuang $\mathrm{H}$, Boucher S, Adams B, Ismail Z. Conformance to evidence-based treatment recommendations in schizophrenia treatment services. Can J Psychiatry 2012;57(5):317-23.
22. Owen RR, Hudson T, Thrush C, Thapa P, Armitage $T$, Landes RD. The effectiveness of guideline implementation strategies on improving antipsychotic medication management for schizophrenia. Med Care 2008;46(7):686-91.

23. Cullen BA, McGinty EE, Zhang Y, Dosreis SC, Steinwachs DM, Guallar E, et al. Guideline-concordant antipsychotic use and mortality in schizophrenia. Schizophr Bull 2013;39(5):1159-68.

24. Cabana MD, Rand CS, Powe NL, Wu AW, Wilson MH, Abboud PC, et al. Why Don't Physicians Follow Clinical Practice Guidelines? JAMA 2004; 282 (15): 1458-1465.

25. Barbui $C$, Nosè $M$, Mazzi MA, Thornicroft $G$, Schene A, Becker T, et al. Persistence with polypharmacy and excessive dosing in patients with schizophrenia treated in four European countries. Int Clin Psychopharmacol 2006;21(6):355-62.

26. Gallego JA, Bonetti J, Zhang J, Kane JM, Correll CU. Prevalence and correlates of antipsychotic polypharmacy: a systematic review and metaregression of global and regional trends from the 1970s to 2009. Schizophr Res 2012;138(1):18-28.

27. Correll CU, Gallego JA. Antipsychotic polypharmacy: a comprehensive evaluation of relevant correlates of a long-standing clinical practice. Psychiatr Clin North Am 2012;35(3):661-81.

28. Maayan N, Soares-Weiser K, Xia J, Adams CE. Antipsychotic combinations for schizophrenia. CochraneDatabase of Systematic Reviews2011, Issue 2. Art. No.: CD009005. DOI: 10.1002/14651858. CD009005.

29. Baandrup L, Allerup P, Nordentoft M, Lublin H, Glenthoj BY. Exploring regional variation in antipsychotic coprescribing practice: a Danish questionnaire survey. J Clin Psychiatry.2010;71(11):1457-64.

30. Brunot A, Lachaux B, Sontag $H$, Casadebaig $F$, Philippe A, Rouillon F, et al. [Pharmaco-epidemiological study on antipsychotic drug prescription in French Psychiatry: Patient characteristics, antipsychotic treatment, and care management for schizophrenia]. Encephale 2002;28(2):129-38.

31. Kreyenbuhl JA, Valenstein M, McCarthy JF, Ganoczy D, Blow FC. Long-term antipsychotic polypharmacy in the VA health system: patient characteristics and treatment patterns. Psychiatr Serv 2007;58(4):489-95.

32. Ostuzzi G, Mazzi MA, Terlizzi S, Bertolini F, Aguglia A, Bartoli F, Bortolaso P, Callegari C, Caroleo M, Carrà G, Corbo M. Factors associated with first-versus second-generation long-acting antipsychotics prescribed under ordinary clinical practice in Italy. PloS one. 2018;13(8):e0201371..

33. Correll CU, Rummel-Kluge C, Corves C, Kane JM, Leucht $\mathrm{S}$. Antipsychotic combinations vs monotherapy in schizophrenia: a meta-analysis of randomized controlled trials. Schizophr Bull 2009;35(2):443-57. 
34. Kogut SJ, Yam F, Dufresne R. Prescribing of antipsychotic medication in a medicaid population: use of polytherapy and off-label dosages. J Manag Care Pharm 2005;11(1):17-24.

35. Leslie DL, Rosenheck RA. Adherence of Schizophrenia Pharmacotherapy To Published Treatment Recommendations: Patient, Facility, and Provider Predictors. Schizophrenia Bul2004;30(3): 649-658.

36. Thornley B, Adams C. Content and quality of 2000 controlled trials in schizophrenia over 50 years.BMJ 1998; 317:1181-4.

37. Leucht $S$, Leucht $C$, Huhn $M$, Chaimani A, Mavridis D, Helfer B, Samara M, Rabaioli M, Bächer S, Cipriani A, Geddes JR. Sixty years of placebo-controlled antipsychotic drug trials in acute schizophrenia: systematic review, Bayesian meta-analysis, and meta-regression of efficacy predictors. American Journal of Psychiatry. 2017;174(10):927-42.

38. Chen RS; Nadkarni PM, Levin FL, Miller PL, Erdos J, Rosenheck RA. Using a computer data base to monitor compliance with pharmacotherapeutic guidelines for schizophrenia. Psychiatric Services 2000;51: 791-794. 


\title{
Uticaj lokalnih vodiča na propisivačku praksu i ishode lečenja kod dugotrajno hospitalizovanih psihijatrijskih pacijenata
}

Ivana M. Iličković ${ }^{1}$, Aleksandar B. Tomčuk ${ }^{2}$, Jovo M. Djedović ${ }^{2}$, Kristina B. Bećir ${ }^{2}$, Slobodan M. Janković ${ }^{3}$

\author{
${ }^{1}$ Farmegra Ltd., Podgorica, Crna Gora \\ ${ }^{2}$ Specijalna psihijatrijska bolnica, Dobrota, Kotor, Crna Gora \\ ${ }^{3}$ Fakultet Medicinskih nauka, Univerzitet u Kragujevcu, Kragujevac, Srbija
}

\section{KRATAK SADRŽAJ}

Uvod: Odstupanja između preporuka za propisivanje antipsihotika u vodičima dobre prakse i njihove primene u praksi se mogu prevazići usvajanjem lokalnih vodiča.

Cilj: Cilj ove studije je bio da ispitamo uticaj lokalno prilagođenih nacionalnih vodiča za lečenje schizofrenije na propisivanje antipsihotika i ishode lečenja u Specijalnoj psihijatrijskoj bolnici Dobrota u Kotoru, Crna Gora.

Metodologija: Studija je bila akademska, IV faza, prospektivna, intervencijska u preporukama zdravstvenog sistema, sa merenjem ishoda pre i posle intervencije. Studija je sprovedena u dva šestomesečna perioda koji su bili razdvojeni usvajanjem i primenom lokalnih vodiča. Propisivanje antipsihotika i ishodi lečenja su bili praćeni u oba studijska perioda.

Rezultati: Ukupno je 111 pacijenata učestvovalo u studiji. Vodiči nisu uticali na (ukupan volumen) ukupnu potrošnju propisivanja antipsihotika, ali je došlo do poboljšanja socijalnog funkcionisanja i komunikacije pacijenata sa okolinom.

Zaključak: Izrada i usvajanje lokalnih vodiča dobre prakse može dovesti do izvesnih poboljšanja u pogledu humanističkih ishoda lečenja, ali za postizanje značajnijeg uticaja na propisivanje $i$ ishode lečenja neophodno je sprovesti složenu intervenciju, u kojoj će lokalni vodiči biti samo jedan od aspekata.

Ključne reči: vodiči, šizofrenija, polifarmacija, bolnički pacijenti, ishodi lečenja 